\title{
Prevention of money laundering and the role of asset recovery
}

\author{
Samuel Sittlington ${ }^{1} \cdot$ Jackie Harvey $^{1}$ (D)
}

Published online: 11 March 2018

(C) The Author(s) 2018

\begin{abstract}
The purpose of this paper is to examine the increasing emphasis of the UK anti-money laundering (AML) legislative framework, on the financial arrangements of criminals. Our qualitative study engaged key stakeholders from the AML environment through a series of focus groups. This included law enforcement; accountants; prosecutors; bankers and, importantly, ex-offenders. We argue that the inclusion of the views of a traditionally hard to reach group of ex-offenders, adds significantly to knowledge and understanding about effectiveness of AML. The research findings suggest that, at first glance, the focus on asset recovery has been successful. However, our respondents shared with us areas of tension and inconsistencies in application of the law, in particular between police and the courts. For example, whether it was better to prosecute the predicate offence separately or in addition to the offence of money laundering; or whether to pursue criminal or civil recovery. We further find that criminals have been able to use their knowledge to circumvent the system, suggesting that greater effort is needed to promote cooperation, rather than competition, in successfully detecting and prosecuting offenders.
\end{abstract}

Keywords Anti-money laundering $\cdot$ Deterrence $\cdot$ Rational choice $\cdot$ Asset recovery

\section{Introduction}

Serious problems require serious solutions. None more so when the economic wellbeing of the country is at stake. In such circumstances it would be hard not to agree that the state should be vested with greater powers with which to address potential harm. Of course the principles of justice dictate that the 'solution' should be proportional to the harm. Further, the

Jackie Harvey

jackie.harvey@northumbria.ac.uk

Samuel Sittlington

sam@sittlington.com

1 Newcastle Business School, Northumbria University, Newcastle NE1 8ST, UK 
diligent public servant should also ensure that any proposed new legal measures imposing a cost to society should always be balanced against the benefits ${ }^{1}$ that will accrue [1].

Money laundering is seen as posing an international global threat, ${ }^{2}$ particularly amongst policy makers, facilitating serious and organised crime and undermining the integrity of the financial system ${ }^{3}$ [see also $\left.2,3,4,5,6\right]$. This 'threat' imagery has been discussed by academics [see for example, 7, 8] particularly with respect to a potential negative impact on the economic wellbeing of the economy. Those academic researchers that have tried to substantiate this evidence are of the opinion that the negative impact is far less certain than it appears to be for policy makers [see, 9, 10]. Indeed, policy makers continue to place emphasis on the scale and threat of the problem [11] as a means of justifying the extensive legal and regulatory framework that has been constructed, and the UK is one of the most assiduous of believers in this threat mantra [12].

In the UK, the framework of legislation is constructed on the basis that money laundering offences are serious in nature and that they 'incentivise crime by rendering it profitable' (Code for Crown Prosecutors). ${ }^{4}$ There is little doubt that the legislative and regulatory changes over the past decade have seen the UK anti-money laundering (AML) landscape alter dramatically, particularly with the introduction of the Proceeds of Crime Act (POCA), 2002. This single piece of legislation, as amended by the Policing and Crime Act, 2009; the Crime and Courts Act, 2013; the Serious Crime Act, 2015; and, most recently, the Criminal Finances Act, 2017 has enabled law enforcement and courts to focus their attention specifically on the financial arrangements of criminals.

The purpose of this paper is to examine the deterrence impact of the additional powers of asset recovery that POCA (and associated legislation) has provided to law enforcement and the extent to which this has enhanced AML. For our diligent civil servant would want to see that the greater intrusion into the affairs of citizens arising from these powers has been justified by law enforcement apprehending a larger number of serious organised criminals and ensuring that 'crime does not pay'. 5 This qualitative empirical work used focus groups to engage with key UK AML stakeholders from law enforcement, accountants, prosecutors and money laundering reporting officers (MLROs). Importantly, our study also includes the view of ex-offenders, adding a valuable additional dimension. The paper starts with a brief review of the history and development of the AML legislative landscape within the UK and provides

\footnotetext{
${ }^{1}$ There is a statutory requirement in the UK for changes to legislation to be accompanied by a cost benefit analysis, referred to as a Regulatory Impact Assessment. Refer to Cabinet Office (2003) Better Policy Making: A Guide to Regulatory Impact Assessment. Available at:

http://webarchive.nationalarchives.gov.uk/20040116235945/http://www.cabinet-office.gov. uk/regulation/scrutiny/ria-guidance.pdf (accessed 15/12/2017).

${ }^{2}$ US Department of State 'money laundering and Terrorist Financing; A global Threat'. Available at https://www.state.gov/j/inl/rls/nrcrpt/2003/vol2/html/29843.htm (accessed 15/12/17)

${ }^{3}$ FATF 'what is money laundering?' Available at http://www.fatf-gafi.org/faq/moneylaundering/ (accessed 15 /12/17)

${ }^{4}$ Available from:http://www.cps.gov.uk/legal/p_to_r/proceeds_of_crime_money_laundering/ (accessed 03/02 /2017)

${ }^{5}$ Harvey $(2004,2008)$ analysed the main regulatory impact assessments undertaken by the UK government in relation to the introduction of the Money Laundering Regulations (1993, 2001, 2003 and 2007) noting that costs were largely under-reported, whilst benefits were unquantified (but assumed to be 'significant') gains to society.
} 
background data published in the public domain on custodial sentencing and assets recovered. It then provides a discussion of the literature around deterrence and rational choice that provides the traditional conceptual framework underpinning academic work in this field. We then set out the method employed for data capture and for its subsequent analysis. The findings arediscussed in relation to two main areas, firstly asset recovery and sentencing deterrent and, secondly, the criminal knowledge and sophistication of launderers which suggest that policy in the field should be further refined to give greater emphasis to asset recovery and that this needs to be supported by greater effort to promote cooperation rather than competition, between the different agencies involved in detecting and prosecuting offenders.

\section{Development of the UK anti-money laundering legislative landscape}

Money laundering had already been included within the provisions of the 1986 Drug Trafficking Offences Act, 1986; the 1988 Criminal Justice Act, 1988 (ss 93A - 93D); and the 1989 Prevention of Terrorism (Temporary Provisions) Act (ss 11-13). ${ }^{6}$ Although it really coalesced with the 1993 Money Laundering Regulations (SI 1993/1933), that were required to implemented the First European Directive Money Laundering Directive and to give legal force in the UK to the FATF 40 Recommendations. ${ }^{7}$ POCA, 2002 was introduced with the express aim of crime deterrence by removing financial benefits, disrupting criminal networks and markets, improving crime detection rates, and ultimately of creating revenue flows for the public purse ${ }^{8}$ [13].

The introductory section to POCA 2002 explains the appointment of an Asset Recovery Agency (subsequently absorbed into the Serious Organised Crime Agency now the National Crime Agency) to provide confiscation orders against persons who benefit from criminal conduct (POCA 2002, Part 1, Chapter 29, Section 1). The overarching role of the Agency had been to reduce crime through criminal investigations and criminal proceedings (POCA 2002, Part 1 Chapter 29, section 2). The legislation sets out how the Director of the Agency will be responsible for the training of financial investigators; accreditation of investigators in confiscation, asset recovery and money laundering investigation; and, the role each plays in furtherance of the Government's crime reduction strategy. ${ }^{9}$ Importantly POCA enabled not only confiscation as part of criminal conviction but also civil based asset recovery and in consequence was

\footnotetext{
${ }^{6}$ Refer, for example, to http://www.icaew.com/en/library/subject-gateways/law/money-laundering/uklegislation-and-regulations. The detail provided covers the period 1993 to 2015.

${ }^{7}$ First European Union Money Laundering Directive (EU Council Directive 91/308/EEC 10 June 1991). The Fourth Money Laundering Directive (arising from the FATF 2012 Recommendations) has been brought within UK legislation through the Money Laundering, Terrorist Financing and Transfer of Funds (Information on the Payer) Regulations (2017)

8 The POCA legislation provided for 'incentivisation' whereby a percentage of the proceeds confiscated would be returned from the Government Treasury to the relevant law enforcement and prosecution services. ${ }^{9}$ H.M. Government (2000) Recovering the Proceeds of Crime. A Performance and Innovation Unit Report, June, Chapter 9, London. Available from http://webarchive.nationalarchives.gov.uk/+/http:/www. cabinetoffice.gov.uk/media/cabinetoffice/strategy/assets/crime.pdf (accessed 15/12/2017)
} 
seen as handing to law enforcement an extremely powerful tool. ${ }^{10,11}$ This development was a significant one as within civil courts the standards of proof are less exacting upon prosecutors (on the balance of probability rather than beyond reasonable doubt), shifting the burden of evidence to the property owner to demonstrate their innocence [14]. A confiscation order handed down by the courts creates a personal debt for the criminal that they are obliged to pay to the State from whatever current assets and/or future income they have available whether or not the proceeds of laundering [13, 15] and irrespective of what happened to the actual proceeds [13]. Where these funds are deemed insufficient, the debt to the state remains in place [15]. As the consequence of a failure to pay is an additional prison term, there is pressure on the criminal to clear the confiscation order no matter the consequences even to the extent of being revisited years later by law enforcement. ${ }^{12}$

A feature of the UK AML legislation that is consistent with other European Countries, is the opportunity provided to law enforcement to prosecute both the predicate offence and the money laundering jointly or separately, whilst circumstantial evidence is sufficient to prove that the proceeds of crime are the benefit of criminal conduct. Under the UK Act, criminal confiscation enables the recovery of an equivalent value of criminal proceeds inferred to have been 'earned' for a period of up to six years (the 'criminal lifestyle'). If criminal confiscation should fail, perhaps because the offender escapes criminal conviction, or because the case collapses at some stage during proceedings, the authorities may turn to civil recovery of the assets arising from those criminal earnings. In this respect the UK went beyond the later EU Directive (2014/42/EU) on the freezing and confiscation of proceeds of crime. That Directive set important standards for the recovery of criminal profits/benefits, ${ }^{13}$ although it did not include civil asset confiscation [16]. In the UK, the most recent piece of legislation concerning AML and the asset recovery regime set up by POCA is the Criminal Finances Act, 2017. This has provided further powers to law enforcement agencies by way of 'unexplained wealth orders' that allow for the seizing of suspected criminal property without the need for a prosecution. They apply specifically to PEPs and to those associated with serious crime. Under the legislation, the court can (on the basis of reasonable grounds that the property held is disproportionate to known income) require the property owner to

\footnotetext{
${ }^{10}$ POCA 2002, Part 2, 3, 4 Confiscation, England, Wales, Scotland and Northern Ireland; Part 5, Civil Recovery of the proceeds of civil recovery; Part 6, revenue functions; Part 7, Money Laundering; Part 8, Investigations; Part 9, Insolvency; Part 10, Information; Part 11, Co-operation; Part 12, Miscellaneous and General.

11 "Crime assets agency 'ill-planned " BBC News Thursday, 11 October 2007, available at http://news.bbc. co.uk/1/hi/uk_politics/7040680.stm (accessed 12/3/10)

12 Example of the use of Section 22 of the Proceeds of Crime Act 2002: Aled Gray was ordered to pay $£ 42,045$ to satisfy a Proceeds of Crime Act confiscation order at Mold Crown Court on Tuesday, October 12, 2016. Gray had originally been convicted in 2012, when his benefit from crime was calculated at $£ 106,000$ Gray could not pay the total and paid $£ 58,480$ leaving a disparity of $£ 47,529$. Under Proceeds of Crime legislation, officers are able to revisit these orders and reclaim assets up to the amount calculated as criminal benefit. On June 6, 2016, officer's executed search warrants at addresses linked to Aled Gray and at one address found $£ 5095$ in cash. Financial enquires found a further $£ 11,950$ in a bank account. Judge Rhys Rowlands granted North Wales Police an application ordering Gray to pay $£ 42,045$ within three months or face a default sentence of two years. Available from: http://www.leaderlive.co.uk/home/2017/10/17 /gallery/anglesey-man-ordered-to-pay-proceeds-of-crime-confiscation-97454/ (accessed 2/12/2017)

${ }^{13}$ Also refer to European Commission Confiscation \& asset recovery: https://ec.europa.eu/home-affairs/whatwe-do/policies/organized-crime-and-human-trafficking/confiscation-and-asset-recovery_en (accessed 2/12/17)
} 
prove a legitimate source for their wealth. Failure to comply with an order can make the property recoverable under the civil recovery provisions of POCA.

\section{Evidence of use of anti-money laundering legislation in the UK - Official data}

The first sentencing guidelines on money laundering were issued in $2014 .{ }^{14}$ Full details on sentencing decisions within England and Wales for money laundering appear in Table 1. Data for this Table were extracted from the Criminal Justice Statistics, published by the UK Government. Maximum penalty on conviction is 14 years and the longest sentence handed down by the courts between 2010 and 2014 was 12 years. ${ }^{15}$ During 2015 (the most recent data) in England and Wales, 2307 prosecutions were brought for money laundering of which 1336 resulted in conviction; this is a conversion rate of 57.9\%, an improvement from an earlier study [49] covering the period 19922004 that showed a conversion rate in the region of 40\%. In general terms it might be inferred that a larger number of criminals are being brought in front of the courts and are being found guilty. Are these the serious organised offenders against whom citizens are to be protected? It would be expected that serious malfeasance would be dealt with in the most serious manner with maximum prison terms handed down. Data from the same Government database shows that over the total period from 2005 to 2015; only six people have been sentenced to more than 10 years; 64 received sentences for a period of between 7 and 10 years; and the vast majority, some 1038, were sentenced for less than one year. Equivalent data for Scotland indicates that for 2013/14 (most recent data) 74 prosecutions were brought with four convictions secured. ${ }^{16}$ Data from Table 1 would appear to indicate that those coming in front of the courts have ambitions less modest than 'undermining the financial system'. From this Table, it can be seen that the average custodial sentence handed down over the past decade is less than two years. Looking at $2015,{ }^{17}$ for those convicted, the average custodial sentence length was 22.9 months. However some 804 were dealt with in lesser ways through, for example suspended sentences, fines, community service or were conditionally discharged. These do not sound like anything more than petty criminals.

Data on asset recovery for the UK is more difficult to analyse. A lack of consistent statistics is not only a problem for the UK as Europol drew attention to inconsistencies in data collection in their 2016 survey of criminal asset recovery in the EU. ${ }^{18}$ Although statistics have been included in the annual reports from the Financial Intelligence Unit (FIU) since the introduction of POCA, that body has a tendency to change the data they report in order to frame recovery efforts in a positive light. For example, the Serious

\footnotetext{
${ }^{14}$ Available at: https://www.sentencingcouncil.org.uk/wp-content/uploads/Fraud_bribery_and_money_ laundering_offences_-_Definitive_guideline.pdf (accessed 2/12/17)

${ }^{15}$ Information sourced from: http://www.parliament.uk/business/publications/written-questions-answersstatements/written-question/Commons/2016-01-12/22147/ (accessed 04/02/2017)

${ }^{16}$ Data for Scotland is available from http:/www.copfs.gov.uk/foi/responses-we-have-made-to-foirequests/40-responses2014/1103-prosecutions-for-money-laundering-offences-r008561 (accessed 17/02/17)

${ }^{17}$ Note that figures will not add up as sentence decisions by the court can relate to cases running from previous years.

${ }^{18}$ Europol (2016) 'Does crime still pay? Criminal asset recovery in the EU: Survey of statistical information 2010-2014
} 
Table 1 Money laundering prosecutions and convictions

\begin{tabular}{lllllllllllll}
\hline Numbers & 2005 & 2006 & 2007 & 2008 & 2009 & 2010 & 2011 & 2012 & 2013 & 2014 & 2015 \\
\hline Proceeded against & 1302 & 2349 & 2293 & 1812 & 2440 & 2719 & 2682 & 2505 & 2349 & 2095 & 2307 \\
Convicted & 566 & 1260 & 1336 & 1275 & 1410 & 1581 & 1519 & 1422 & 1269 & 1143 & 1336 \\
$\quad$ Sentenced & 545 & 1232 & 1310 & 1260 & 1375 & 1555 & 1487 & 1389 & 1235 & 1122 & 1300 \\
$\quad$ Conditional Discharge & 50 & 119 & 139 & 101 & 105 & 125 & 94 & 95 & 78 & 57 & 74 \\
$\quad$ Fine & 52 & 107 & 98 & 84 & 91 & 89 & 68 & 73 & 66 & 57 & 61 \\
$\quad$ Total Community Sentence & 231 & 486 & 451 & 333 & 366 & 467 & 420 & 363 & 265 & 221 & 251 \\
$\quad$ Suspended Sentence & 25 & 137 & 223 & 304 & 301 & 343 & 351 & 377 & 356 & 370 & 407 \\
$\quad$ Total Immediate Custody & 178 & 361 & 360 & 408 & 488 & 503 & 533 & 461 & 462 & 402 & 491 \\
$\quad$ Total Otherwise Dealt With & 3 & 13 & 28 & 23 & 16 & 23 & 9 & 15 & 3 & 11 & 11 \\
Average Custodial Sentence & 19.6 & 18.8 & 17.9 & 20.5 & 20.1 & 20.4 & 21.0 & 21.0 & 23.6 & 20.7 & 22.9 \\
$\quad$ Length (months) & & & & & & & & & & & \\
Average Fine (£) & 382 & 443 & 357 & 269 & 316 & 288 & 347 & 1006 & 634 & 136 & 518 \\
\hline
\end{tabular}

The data within this table will not sum as not all cases are concluded within a calendar year. So using 2015 as an example there were 2307 prosecutions brought and during the year 1336 convictions for money laundering. Of the sentences passed (1300) the outcome includes a range from immediate custody to conditional discharge (totals 1295); of those given a custodial sentence the average length in 2015 was 22.9 months. Where fines were imposed, the average size was $£ 518$

Source: extracted from Criminal Justice Service Outcomes by Offence 2005 to 2015 Available from: Criminal Justice Statistics outcomes by offence data tool - Gov.uk; version May 2016;

http://www.gov.uk/government/uploads/system/uploads/attachment_data/file/524326/cjs-outcomes-byoffence.xlsx

Organised Crime Agency [17] (page 32) provided details of cash seizures $(£ 9.2 \mathrm{~m}$ 2008/9) confiscation orders ( $£ 29.7 \mathrm{~m} \mathrm{2008/9)}$ ) and civil recovery ( $£ 16.7 \mathrm{~m} \mathrm{2008/9)}$. Most recently, however, reporting is less transparent with changes in what data is being collected and disclosed within the public domain. The National Crime Agency $(\mathrm{NCA})^{19}$ is more circumspect in disclosing information on asset recovery arguing that due to the complexity of cases, recovered assets failed to indicate the wide amount of disruption to criminal activity, itself regarded as evidence of success. By way of example, referring to its first year of operation: 'NCA operational activity resulted in nearly $£ 22 \mathrm{~m}$ denied to criminals in the UK and almost $£ 104$ million being denied to criminals impacting on the UK by overseas partners'. Further 'Since the start of the $N C A$, its activity has led directly to operational partners seizing around 116 million in cash and making around 150 related arrests' ${ }^{20}$ Similarly, in their Asset Recovery Strategy document 2014, ${ }^{21}$ the Crown Prosecution Service (CPS) indicated that 'The total amount of assets recovered across the CJS in 2012-13 was £152.2 million. This figure combines money recovered from confiscation, cash forfeiture, civil recovery, criminal taxation, and international asset sharing. The money recovered under confiscation orders alone was £105.4 million’ (p. 4).

\footnotetext{
${ }^{19}$ The NCA was established in 2013 and replaced SOCA.

${ }^{20}$ Available from: http://www.nationalcrimeagency.gov.uk/news/news-listings/549-nca-approach-to-criminalassets (accessed 14/03/17)

${ }^{21}$ CPS (2014) Asset recovery Strategy, June, available from: www.cps.gov.uk/publications/docs/cps_asset_ recovery_strategy_2014.pdf (accessed 23/02/17)
} 
Of course, such collective large-figure sums create an impressive appearance and as 'proof of the pudding' might persuade our civil servant the approach is fully justified. We consider it more informative to look at the composition of these figures. The CPS discloses that during this period $£ 90$ million was recovered from confiscation orders (figures taken from Joint Asset Recovery Database, JARD); there is no indication if this was from a single order or indeed from thousands of separate orders. Such a question is relevant in light of the evidence on sentencing that has already been discussed. For if recovery is comprised of many small amounts, questions can be asked about the type of offenders coming in front of the courts. For example, an earlier study analysed data held on JARD for the years 2003/4 to 2005/6 and determined that the median value for confiscation orders was between $£ 300$ and $£ 500$ [18]. The authors further noted (p. 296) 'it is believed these reflect multiple payments against the same case number, particularly in respect of cases involving drugs' whereby small-time drug dealers were required by the courts to make small monthly payments; a finding that is equally borne out by a large-scale study that analysed Dutch asset recovery cases [19]. It is, difficult to determine from this data whether the approach is indeed preventing serious and organised crime from undermining the financial sector and others, [see for example 18, $19,20,21,22,23,24]$ have already questioned the validity of this argument.

In light of the apparent disparity in the views of the policy makers and academics, it might be reasonable, to return to the objectives attached to POCA itself, which, as already discussed expressly focussed on crime deterrence. This would enable us to approach the subject of asset recovery and assess 'effectiveness' rather than in terms of the scale of assets recovered, but in terms of its impact on the decision-making by the individual criminal. Before presenting our findings in this regard, the next section briefly considers relevant literature.

\section{The criminal profit formula and effectiveness of approach}

Neoclassical economics informs us that individuals are motivated by self-interest and (rationally) seek to maximise personal utility. To the extent that criminals are motivated by personal profit, it would be rational to arrive at a measure of overall utility by balancing the benefit from the criminal activity against the cost that might be incurred. In the case of acquisitive crimes (for example, burglary or fraud), a monetary value can be ascribed to arrive at benefit. The short-term costs might include the 'tools' required to commit the offence. In addition, there is a longer-term cost, calculated as the severity of sanction imposed, multiplied by the probability of being caught [25]. In these circumstances, a criminal would commit resource to those crimes where the present utility derived exceeds the sum of the current costs of execution, plus the future costs of apprehension, traditionally expressed in terms of a custodial sentence [26, 27].

This statement of affairs is familiar to students of criminology as rational choice theory $[28,29]$. Although rational choice had been developed to provide a theoretical framework for situation crime prevention [30,31], its objective was to look at the offender's perceptions of risks, effort and accrued rewards. Since its original formulation, rational choice theory has been the subject of academic scrutiny with further refinements being made. Most recently, [32, 33], the discussion has distinguished between application within two schools: the neoclassical utility focus in which criminal decision makers are 
seen as objective cost-benefit calculators [34] able to derive the outcome that maximises their own personal utility; and studies that accept the fallibility inherent in human decision making and that recognises imperfect or bounded rationality [35]. In the latter case, an individual's ability to weigh accurately these different sides of the scales of risk and reward is of necessity bounded by limited availability of information and the accuracy with which they can evaluate 'future' costs in terms of their equivalent current impact. Under these conditions, the possible future jail sentence is outweighed by the immediate benefits accruing from the crime so that in terms of the criminal decision making, these immediate gains weigh disproportionately within the 'criminal profit formula' [36].

One of the main problems with rational choice is the presumed a priori decisionmaking by the criminal. Certainly, they will be mindful of the risks involved $[37,38]$ but it is difficult to envisage that prior to committing a crime a potential criminal will calculate whether there is a positive net present value associated with the undertaking [26]. Although others have, for example, observed criminals adjusting their operations to lower risk activities such as a criminal moving away from involvement with drug trafficking to that of cigarette smuggling [39] or out of armed robbery once such crime became too high risk [40] towards the lower risk and infinitely richer pickings available from white collar crime [41, 42].

Application of theory and specifically the principles of restorative justice whereby criminals should not be able to benefit from the fruits of their illicit enterprise [15], suggests that in constructing the criminal legislative framework, it is the Government's responsibility to ensure the 'cost' imposed by the criminal justice system on the offender exceeds any identified benefit derived by them from committing the offence. This is achieved by carefully stacking the weights onto the deterrence side of the scale [19, 37, 41, 43, 44] with POCA, 2002, providing a useful additional restorative component [15] elsewhere discussed as a 'tax rate' levied on criminal income [36, 37]. This has proved most effective as it enabled the state to move the monetary 'gains' from the benefit side of the scale and smartly reposition them on the 'cost' side. Thus: 'many criminals face the double blow of being hit hard in the pocket'. ${ }^{22}$

Despite the positive endorsement for the use of asset recovery by law enforcement, academics remain sceptical regarding its impact on criminal activity which had not been verified "on a large sample of offenders" [23]. Some academics argue that it could deter crime by reducing the expected benefits accruing from such activity, as well as disrupting networks and markets [45, 46]. Others, however, are more equivocal arguing that success is very dependent on the type of criminal targeted [47]; that those apprehended lacked sophistication [see, for example, 18, 19, 21, 48, 49]; or, that the threat of prison is probably a stronger deterrent, particularly for white-collar offenders. It has also been suggested that there are few assets actually available for confiscation simply because criminals consume the proceeds immediately or soon after obtaining them [46, 47, 50-55]. It is probably more realistic, however, that this consumption through immediate acquisition of goods and chattels may

\footnotetext{
${ }^{22}$ Assistant Chief Constable Suzette Davenport Staffordshire Police "Record criminal assets are seized" BBC News 7 August 2006 available at http://news.bbc.co.uk/1/hi/england/staffordshire/5252732.stm (accessed 12 $/ 3 / 2010)$
} 
more likely align to the level at which the criminal operates, it being more common with lower level felons [56]. There is also evidence that the more sophisticated the criminal, the more likely they are to use schemes both elaborate and simple to get around the need to prove "where the money came from'. Hence, the move towards renting rather than purchasing/owning high value assets or gifting criminal assets to third parties that would otherwise have been seized by the authorities. In such manner, in some cases they are able to derive full consumer benefits without fear of loss [57]. However, under lifestyle decisions criminals need to dissipate assets at an early stage as in proceedings, recoverable amounts may include joint ownership with third parties.

A final area of academic criticism centres on the incentivisation of law enforcement which argues that policing priorities have been skewed. Rather than hitting the crime targets that the POCA legislation intended, they, instead, focus on the easiest pickings of the criminal fraternity; for example, those cases which are easiest to prove or have identified assets and without the need for a resource intensive, time consuming and complex financial investigation $[15,18$, $21,58-60]$.

\section{Method employed}

Previous empirical research has highlighted problems of data access when working in this field [18, 44, 61-64]. In consequence, use is made (often unquestioningly) of statistics drawn from official government ${ }^{23}$ and law enforcement records, with less emphasis on primary data gathered from experienced, knowledgeable AML stakeholders. The purpose of this research was, therefore, to investigate the extent to which the loss of assets can be seen as providing an additional deterrent that would improve the effectiveness of AML. To consider this we had to look beyond law enforcement and engage with the criminals themselves. Our work employed a qualitative approach through focus groups drawn from representatives of those involved in, and impacted by, AML. To provide the context, the focus group study formed part of a larger mixed methods study ${ }^{24}$ that involved four phases of data capture and analysis. The purpose of the focus groups was to validate the themes from the literature in preparation for the next stage of the study. However, in addition, what emerged was a large amount of very rich qualitative data upon which this paper is based. As set out in Table 2,

\footnotetext{
${ }^{23}$ For an extensive critique refer to Duyne, P.C. van, Harvey J., \& Gelemerova, L., (2016) 'The Monty Python Flying Circus of Money Laundering and the Question of Proportionality' Chapter 10 in 'Illegal Entrepreneurship, Organized Crime and Social Control: Essays in Honour of Professor Dick Hobbs' (ed) G. Antonopolous, Springer, Studies in Organized Crime 14.

${ }^{24}$ This wider doctoral study (Sittlington 2014) used a four-phase sequential strategy employing mixed methods of qualitative and quantitative disciplines, triangulated to produce statistically significant results. This research identified major themes from the literature. These themes were used to inform the questions posed within the focus group interviews (reported upon here). The focus groups were used to validate the themes that had emerged from the literature to inform a wider survey questionnaire, the results of which were subsequently verified through principal component analysis.
} 
Table 2 Groups and dates

\begin{tabular}{lll}
\hline Focus groups & Stakeholder & Date of meeting \\
\hline Group A (5 persons) & Law Enforcement & $6 / 3 / 2011$ \\
Group B (4 persons) & Forensic accountants & $7 / 1 / 2011$ \\
Group C (4 persons) & Prosecutors & $29 / 8 / 2011$ \\
Group D (4 persons) & MLROs from banks & $30 / 10 / 2011$ \\
Group E (3 persons) & Ex-offenders & $17 / 11 / 2011$ \\
\hline
\end{tabular}

the sample comprised five key stakeholder groups, the first four of which comprised: law enforcement and prosecutors representing those involved with legal aspects; accountants and bankers representing those subject to regulatory compliance. While other studies in the field have employed a similar approach [65-67], the contribution made by this work is that it included a fifth group comprised of former offenders, ${ }^{25}$ traditionally a group that are hard to reach. ${ }^{26}$

We recognise the limitations of qualitative research $^{27}$; however, in managing these we were careful to follow the advice of others [68-71] particularly with respect to the number and composition of each group. It was, therefore, important to keep groups stakeholder specific and to restrict numbers to allow for full contribution by all participants within each of the groups and care has been taken to report dissenting opinions and views. Each meeting lasted between one and two hours. Given that these individuals each have distinct knowledge and understanding of the operation of the AML framework, the approach enabled us to understand their way of thinking [72] and to give voice to their stories and experiences [70]. As mentioned above, themes to guide focus group discussion were extracted from the literature on money laundering and from money laundering policy (drawing from both academic and professional sources). ${ }^{28}$ Support for this method is underpinned through the work of Braun and Clarke [73] and Bernard [74]. As shown in Table 3, the broad themes that emerged were captured under a small number of core headings: legislation; criminality; SAR process; spend; influence;

\footnotetext{
${ }^{25}$ Following University Ethics Committee Guidelines consideration toward safety of researcher, participant, and obtaining information that may compromise the participants, or their position was paramount. All other procedures relating to consent and anonymity were followed. Ethical clearance for the study was granted on 15 th July 2011.

${ }^{26}$ Access to ex-offenders was facilitated by a third-party introduction to a former prisoner who was now working within a government community scheme. He would eventually be one of the participants in this exoffender group. A meeting was arranged with him to discuss the research and the objectives of the focus group interviews. A suitable venue was offered at a local community centre and a list of the other participants who would be in attendance was made available.

27 The limitations of the method refer to the small number of participants, the possibility that one participant might dominate and influence the collective opinion of the group, the restriction of groups that excluded respondents from a wider geographic area and that the interpretation of data (including example quotations) is down to the researcher. We have attempted to mitigate these limitations by following the advice of others particularly in respect of constructing and managing the focus groups and in how the main themes emerged from the analysis of the transcripts. Obviously we cannot claim generalisability from the results.

${ }^{28}$ Empirical literature in the field tends to be quite limited, we therefore employed purposive sampling to produce a range of papers that gave a geographical spread and covered a time period from 1991 to 2011.
} 
Table 3 Combination of policy and literature based themes

\begin{tabular}{lll}
\hline FATF Themes & Literature Themes & $\begin{array}{l}\text { Core 'headings' and } \\
\text { basis for question } \\
\text { prompts }\end{array}$ \\
\hline Legal system & Policy & Legislation \\
Regulation and supervision & Regulation & Criminality \\
Law & Crime trends & SAR process \\
Enforcement & Crime types & Spend \\
Money laundering prevention & Crime reports & Influence \\
Restraint and confiscation & Investigation & 'Other activities' \\
International & Criminal behaviour & \\
& Prevention & \\
& SAR reports & \\
& Bank secrecy & \\
& Shadow economy & \\
& Proceeds of crime & \\
& Restraint/confiscation & \\
& Cash movement & \\
\hline
\end{tabular}

and a generic 'other activities'. Material generated within each theme provided the six-broad question prompts that were employed to assist and to regulate the flow of discussion and to capture the views from the focus group. ${ }^{29}$

As expressed above and consistent with others $(68,72,75)$ it was important to ensure that analysis of the data (comprising some 60 thousand words in total) accurately represented the opinions and experiences and the participants' 'voice'. The group sessions were spread over a period of 10 months, so it was possible to take interim findings from one group to the next. Focus group transcripts were read to get a clear understanding of the flow of the discussions. Attention was paid to areas of agreement or of dissent both within and between the groups [75-79]. The approach consisted of an initial informal analysis of the text that searched for key words and discussion describing AML processes, with quotations being extracted that illustrated these key points. The initial manual analysis of text was reinforced through use of the qualitative data analysis software NVIVO9 to ensure that no themes had been missed. ${ }^{30}$

\footnotetext{
${ }^{29}$ The question prompts were employed to start and move discussion. They were deliberately kept high level and generally asked: What are your views on sentencing and confiscation as a deterrent? What are your views on incentivisation -money making exercise or deterrent? What is your view on hierarchy of crime i.e. organised crime? Are there levels of money launderers? Are there professional money launderers? What would you change in the Proceeds of Crime arena?

${ }^{30}$ Each coded interview transcript was imported and set up as a case. The themes drawn from literature were also imported so that any comparisons would be made between the cases (themes and transcripts). Each of the prompt questions was set up as a query and the data extracted using NVIVO9. The results provided all responses in that subject area (as questions were not put directly to each group in the same manner i.e. word for word, but rather questions around the subject area).
} 


\section{Findings and our contribution}

The data presented here is organised in relation to two main areas: the first is in relation to 'Asset Recovery and Sentencing Deterrent'; and the second concerning 'Sophistication of Criminals - Criminal Knowledge'. These two areas (extracted from exploratory analysis of the full data set from the wider study) emerged as significant factors ${ }^{31}$ influencing AML policy in the UK.

\section{Asset recovery and sentencing deterrent}

The introduction of Civil Recovery powers appears to have strengthened the hand of those charged with enforcing the law. The view of Group C, Prosecutors, was clear that asset recovery was a legitimate and welcome addition to the law enforcement armoury and should be expressly included as a deterrent:

\section{I mean all the articles that you read talk about it being a draconian piece of legislation, but it is draconian because it's there to punish, it's there to punish and to get back the proceeds of crime. And I think that is where a lot of practitioners perhaps on the defence side, and you know possibly the judiciary on occasion find that difficult'.}

It was also considered valuable as a 'backstop' in cases where prosecutions proved difficult. For example, in discussion about the choice of civil or criminal prosecution, Group A, Law Enforcement suggested: 'Either one of those things [The use of criminal proceedings or civil recovery] should end up with a jail sentence or some sort of a deterrent... Well if they're convicted that's deterrent. But if they can't even get them into the court in the first place.....' This comment is interesting because the objective when the legislation was introduced (as stated at the time by then Prime Minister, Tony Blair), was to use the criminal courts for asset recovery, however, over time this has been replaced by emphasis on civil recovery powers. There was agreement, however, that the most effective deterrent would be delivered through a combination of both confiscation and a prison sentence. By way of example:

\footnotetext{
${ }^{31}$ From the factor analysis in the wider study, the following were identified as statistically significant: Sentencing/Deterrent

The penalties for money laundering crime are too lenient; The disparity in sentencing for money laundering in the UK is too wide; A person convicted of drug trafficking is likely to receive a more severe sentence than the person who laundered his drug money; Professionals are treated differently in court sentencing for money laundering; Financial crime which includes money laundering is not seen as a serious problem; Money laundering is a consequence of another crime such as drug trafficking but is treated differently in court in sentencing; Financial crime appears to be treated more leniently in court than other crimes.

Criminal Knowledge

Money launderers have to be aware of law enforcement tactics; Money launderers have to have knowledge of AML policy. In addition, a third component, not reported upon here identified Reporting/Compliance. The banking system in the UK does a good job in preventing the use of accounts to launder criminal money; The current regulatory AML framework is sufficient to dissuade professional from being involved in money laundering; AML policy in the UK appears to be effective; The regulators are an effective force to ensure reporting institutions comply with regulations.
} 
'....I think the 2002 legislation made the confiscation process a lot easier and a lot more wide spread against the criminal... certainly from my role as a confiscator that it's quite clear that they fear that, more than they ever fear a prison sentence. That in itself the confiscation scheme and the 2002 Act has certainly made the criminals an awful lot more aware of what .... police can do and can't do'. Group A, Law Enforcement. And:

'I would distinguish between the two, the actual sentence in terms of custody in money laundering cases in my experience is not of huge deterrent value because the sentences tend to be quite low. But it's the confiscation which I think is a huge deterrent that really hits them where it hurts, in their pocket'. Group D, MLROs.

And it is the asset recovery perspective that appears to have had an impact on the criminals.

'Civil recoveries, we're making good use of that now, case in point... [individual in location]... currently the subject of a SOCA investigation...getting taunts in the street that his properties are going to be taken from him. SOCA's going to take your house, take your pubs...becomes a figure of ridicule' Group A, Law Enforcement. Further: 'I think there are quite a few cases where a felon would be happy enough to plead guilty to whatever charges are before the court because they know they're not looking at substantial jail time, whatever but when it comes to taking their assets off them...that's when the real fight comes' Group C, Prosecutors.

There were dissenting voices who maintained that stiff sentences alone would provide adequate punishment, therefore, correct sentencing should be a sufficient deterrent without the need for asset recovery. Further, not everyone was of the view that the asset recovery powers were being used to deter the worst types of felons. Thus one of the groups thought that asset recovery by SOCA had been skewed by the focus on financial targets: 'the whole issue is to get the money in quickly... and it's very commercially driven...SOCA that's the mind-set they need to bring...how can I make a profit in this' (Group B, Accountants). This rather points to the FIU being influenced by the government asset recovery targets. Rather than going after the most serious criminals they are instead taking on those cases that are easier to conclude to save on expensive administration, resource intensive investigations and lengthy court procedures.

Focus groups frequently returned to problems with being able to take prosecutions through the court. 'We haven't got the information we need to take the prosecution decision and we end up withdrawing the charges in those cases' (Group C, Prosecutors) or to secure convictions. So rather than prosecute for the predicate offence, asset recovery and gathering in of criminal funds provides a 'route of least resistance'. As a consequence, and somewhat rationally, a civil recovery appears to be preferred to a costly time and resource intensive investigation even though a prima facia case is presented. It is also possible that law enforcement, prosecutors and the judiciary, instead of seeing asset recovery as an additional tool, are in reality approaching it as being interchangeable with a custodial sentence. 'We've even had instances where the judges are starting to equate; they're starting to trade off a criminal sentence with a confiscation order' (Group C, Prosecutors). Participants argued that the current approach to 
sentencing was not as effective as it could be, highlighting the need for 'Stricter sentencing for serious crime'. Consistent with the sentencing data discussed earlier, the groups pointed to the courts seeming more likely to hand down suspended sentences, short prison sentences or fines. Court proceedings point to a distinction between the money laundering offence and the predicate crime in how they are prosecuted and sentenced. For one participant within law enforcement, the disparity in sentencing for 'related' crimes such as drug trafficking and money laundering simply did not make sense $\mathrm{e}^{32}$ and that there was "no message that money laundering and predicate crimes are equal'. Another participant suggested that the judiciary needed education regarding the sentencing guidelines with further guidance through both the court of appeal and the sentencing council. ${ }^{33}$ In general, the view is that current rules are inconsistently applied across the UK courts and in consequence reduce the effectiveness of the legislation. As participants of the law enforcement group suggest: 'So that's a question for prosecution services, CPS, PPS. Why are you unwilling to prosecute when we have evidence to prove, especially in line with standalone money laundering'? Whilst recognising that sentencing is determined by the circumstances of each case, there was general agreement among the participants that the 'sentencing factor' in combination with civil recovery would prove a highly efficient and a more powerful deterrent, improving the overall effectiveness of AML policy. This was because they did not view sentencing on its own as an effective deterrent - certainly for the types of offenders coming before the courts and this may well be because of the identified leniency in sentencing decisions. Ex-offenders suggested that the risk of custody was indeed factored into decision making but from the perspective of being a known risk and thus part of the job rather than any real deterrent:

'You know in the old days you had the, what was termed, the ordinary decent criminal, the burglars and people like that, getting caught and jail was part of their life...they knew it was down the road there somewhere...I think they understand there is a chance and they plan accordingly'. Group E, ex-offender.

They are, therefore, more interested in the emphasis being placed on the confiscation side of proceedings: 'why is there emphasis on the civil side? is it because it's an easier system, an easier way of getting money off people for the government' (Group E, exoffender). It emerged that defence barristers are more likely to be instructed by their clients to 'make a deal' on the confiscation side rather than appeal the sentencing.

Returning to the perceived interchangeability between a sentence and asset recovery touched upon earlier it is apparent that within the court system sentencing and confiscation are weighed against each other to provide a 'just' redress. Former offenders, very clearly identify the double jeopardy of two penalties for one crime (also see, [56]). Despite the wording of the Act that requires confiscation to be dealt with at the end of sentencing and not as part of the sentencing process, courts are inclined to balance the

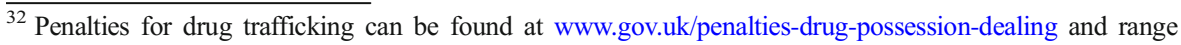
from between 7 years to life imprisonment. Penalties for money laundering can be found at www.gov. uk/guidance/money-laundering-regulations-appeals-and-penalties and can carry a sentence of up to 14 years imprisonment.

${ }^{33}$ Indeed, there was a suggestion that the results of this study should be presented to the Home Office to stimulate a review within the Public Prosecution Service and Judiciary.
} 
two. Criminals and defence barristers are aware of this and use the system to their advantage. What follows in the court process is three-way 'horse trading' between, prosecutors, law enforcement and the defendant's defence team, each looking for a different outcome. The defence team want a lower confiscation for the client; the prosecution wants a guilty plea and less court time; and law enforcement want a conviction for the criminal offence and full confiscation. Not all of these can be achieved, hence the 'deal-making': 'The last one that I dealt with I'm trying to ring the PPS before the barrister rings the PPS to tell them that he's just done a deal in the sum of... And I'm ringing the PPS to get in first to say he's trying to do a deal here and he shouldn't be doing a deal' (Group A, law enforcement). This, we found, created tension and evident distrust between law enforcement, prosecutors and defence teams.

The results from this section imply that whilst recognising that sentencing is determined by the circumstances of the individual case, there was general agreement among the participants that the 'sentencing factor' in combination (rather than interchangeable) with civil recovery would prove a more powerful deterrent, improving the overall effectiveness of AML policy. Criminals have responded to asset recovery as a very real additional risk that has to be mitigated but rather than desisting from crime they seem to look to their defence teams to negotiate the best 'combination outcome' as further elaborated in the next section.

\section{Sophistication - criminal knowledge}

If 'unbounded' rational choice theory holds, a criminal will mentally review the risks and rewards prior to committing an offence. We have already indicated that the exoffenders in our focus group did consider their actions where they had knowledge of ways in which they might be found out, for example: talk between offenders in prison as to how they were caught; not wanting to let their associates down; or bravado associated with the crime. But does the thinking refer to questions such as: What happens if I get caught? What can I get out of this? Will I go to prison? Will I get fined? Or, is it something altogether different? Views shared by our respondents in Group E definitely emphasised 'bravado' and 'credibility' of the offender.

'- it's all, there's the emotion, there's the bravado, there's the legitimacy supposedly of what you're fighting for or against ... all that comes, and the risk, you know' and 'There may also be a bit of credibility about, around maybe serving a prison sentence as well in certain circumstances'. The 'cost' the offender considers is not about what the sentence might be, but is about the size of confiscation that will be calculated. For those higher-level criminals, losing their criminal empire is a deterrent although this will not necessarily hold for those operating at the street level who tend to spend as they go. The more sophisticated criminals should indeed be concerned about confiscation as our data indicates that the other parties (judiciary, police and prosecutors) are all focused on the offender's assets: 'But the bottom line of it is, you know the bottom line to your question is, confiscation is more of a deterrent than sentencing' (Group A, law enforcement). In consequence, if criminal assets are seized, through greater use of confiscation (whether confiscation takes place after conviction or through civil recovery) there does appear to be evidence of deterrence. Responding to this, evidence from this study suggests that criminals are employing tactics to hide assets in a way that 
removes them from beyond the reach of asset recovery powers: 'We're finding a lot more hidden asset, where assets are hidden in third party type thing" and

"Just in the last 18 months to two years instead of getting a straightforward case where you get an individual or a company, you now get companies and they're chains and there are groups of them. And it seems, I'm not sure if it's deterring the crime as opposed to making them more determined not to get caught. Or not determined, more determined to have a limited company take the fall for it where they can't be hit'. Group C, Prosecutors.

Notwithstanding the efforts of the FIU, use of multiple bank accounts in multiple jurisdictions adds to those difficulties. Even with the use of mutual legal assistance from other countries that helps UK law enforcement access data in foreign jurisdictions, the time taken to produce the evidence adds to potential problems:

'Once it goes cross border it grinds to a halt because the natural jurisdictions don't want to work together. See your biggest issue for us in the level of crime that we're dealing with is, a lot of it is so slow for us to investigate because it is outside the immediate jurisdiction'. Group A, law enforcement.

In addition, self-laundering prosecutions may not be possible in some jurisdictions due to difficulties with predicate offence definitions $[2,80]$. Within the UK, although it is possible to prosecute self-laundering as a standalone offence it was apparent from our respondents that rather than do this, prosecutors would prefer to gather enough evidence to pursue, in addition, the predicate offence. Although this might be an efficient way of managing workload, this approach appeared to have been more with an eye to mitigating against the risk of failure of a prosecution. A position that apparently exasperated our law enforcement group who would rather just secure the conviction.

In contrast to the three - tier model currently being applied by UK law enforcement, the National Intelligence Model (NIM), ${ }^{34}$ several activities presented and discussed by our focus groups suggest a two-tier spending regime by criminals. The NIM is a model for policing that provides strategic direction and tactical resourcing decisions from the management of information and intelligence that is received. In brief, the model works at three levels: level 1 deals with crime at a local or command level; level 2 deals with crime at a regional level and level 3 deals with serious and organised crime that is usually national or international in operation. The two tiers of criminals that emerged from our study embrace, firstly, a lower level criminal who spends his criminal proceeds as he receives them; and secondly, a higher-level criminal who contracts the use of professional money laundering facilities. The lower level criminal will typically be involved in low level street crime, such as drug dealing, burglary and theft that is largely cash based. Where this is not the case they would generally self-launder ${ }^{35}$; something that is viewed as harder to detect due to their deliberately limited involvment

\footnotetext{
${ }^{34}$ For a full description of National Intelligence Model (NIM) see: www.acpo.police.uk

35 "Own proceeds" or "self laundering", where the defendant in a money laundering case may also be the author of the predicate crime; http://www.cps.gov.uk/legal/p_to_r/proceeds_of_crime_money_ laundering/\#Main_types_of
} 
with the financial system. The higher-level criminals embrace high income crime, such as drug trafficking, cigarette smuggling and fraud. As these yield larger sums, such criminals needed to employ the help of others:

'But they're learning as the years have gone on from the Proceeds of Crime Act because initially the people would have put a wad of money in a child's savings account... Or in his mother's... Yeah that we could have got it very quickly. Now they're having to think much smarter, that they have to take the money away from themselves and their families completely' and

'I would say there are professional money launderers at the top end, there has to be, whether it's laundering cash or just laundering cheques or money that's come across a computer screen that's just bouncing around different accounts. I mean there has to be. Someone who launders money, big sums, it's going to be pretty much a full-time job, and they're going to take their cut for that'. Group B, Accountants.

As discussed in the preceding section, our respondents were of the view that offenders operating at the higher level have more to lose if prosecuted and their assets seized. Hence they are likely to employ professional people to assist with asset hiding. The MLROs from banks (Group D) were of the view that such professional money launderers required knowledge of AML processes. "I mean if I was a criminal the first people I would employ would be, I would employ a good accountant to go through the JMSG guidance notes to see where the loopholes are. Or I would put someone inside a bank to understand where the bank is weaker, you know, is maybe potentially paying lip service". Further that access to knowledge around AML policy is readily available on line or in libraries. As earlier mentioned, many criminals discuss their cases and criminality in prison [20]. Police methods of collecting evidence and detaining offenders are written in case files and are portrayed on an almost daily basis in film and media. There is consensus from participants that money launderers use weaknesses in the AML system to their advantage "Criminals will establish very quickly where the weak links in particular banks are and will home in on that" (Group C, Prosecutors).

\section{Conclusions}

Returning to our civil servant who was tasked with ensuring that the legislative changes being introduced and the additional asset recovery powers were both proportional to and justified by the 'threat' posed by money laundering; how has he faired? Well, our focus groups suggest that that the choice by individuals to commit money laundering offences is not bound by the deterrent effect of going to prison, this is simply part of the job. However, they do fear losing their assets from the confiscation that follows. At first glance it can be concluded that the additional powers of asset recovery have been successful. Further that the fear of loss of assets was (logically) greater from those that had more to lose, the more sophisticated criminals. Law enforcement respondents viewed lighter sentences as being symptomatic of court leniency. However, the views of the ex-offenders indicate that the lighter sentences might in part reflect that higherlevel criminals are actually effective at hiding their assets. Despite this, there was no 
evidence that even those operating at this level were on a scale that was undermining the financial system. Consistent with discussion in the literature, there was agreement amongst our respondents that those being apprehended and brought through the courts were not the criminals who were the original target of the legislation but rather the lower level cash-based ones. From this our administrator might conclude that he was misled by the original justification but that there has been some deterrence benefit brought about, albeit at a lesser scale than might have originally been envisaged.

However, the focus groups also shared with us areas of tension and inconsistencies in application of the law, something that does not appear to have emerged from other studies. For example, whether it was better to prosecute the predicate offence separately or in addition to the offence of money laundering; or whether to pursue criminal or civil recovery. It is apparent that money laundering alone attracts lighter sentences and that, from the perspective of our respondents, courts appeared to consider confiscation as an alternative rather than addition to a custodial sentence, being fully prepared to negotiate trade-offs in arising at the appropriate restoration. This appears to be at odds with the intention of the legislation that provides for confiscation to be dealt with at the end of the sentencing and not instead of sentencing. The POCA legislation provided for three parts to the court proceedings dealing with the criminal case: conviction for the predicate offence; conviction for money laundering; and finally, the confiscation proceedings. The point being that the legislation intended that all three are components would be applied jointly rather than as a 'pick and mix'.

The suggestion that prosecutors were getting 'two bites of the cherry' with money laundering being an easy charge to add to an existing predicate offence was not substantiated by our respondents, neither did we find evidence as Cuellar [56] claimed, that prosecutors use money laundering statutes in place of predicate offence legislation. Indeed, prosecutors stated their preference that the predicate crime be pursued rather than money laundering charges, seemingly being happy to leave the money laundering to civil recovery action instead. Perhaps as the civil recovery process is applied with a lower burden of proof ('balance of probabilities' as opposed to 'beyond reasonable doubt') this may seem a logical approach but it takes away both from the theoretical perspective of prosecuting criminals and of the intention of the POCA that had the very clear objective that 'crime should not pay'.

Our focus group study found that the most effective deterrence combination is civil recovery (targeting both levels of criminals) alongside stiffer sentences. However, for this deterrence to be effective, co-operation and partnership are powerful allies that do not appear to be quite as they should be. It is evident from the focus groups that enforcement agencies do not see eye to eye in discharging their AML function. When law enforcement attempt to prosecute for money laundering they do not have the full support of the CPS, feeling that prosecutors are more readily persuaded to negotiate an outcome with defence counsels. The ability of criminals to exploit this position has reduced the effectiveness of the UK AML legislation.

\section{Compliance with ethical standards}

Conflict of interest The authors declare that they have no conflict of interest.

Open Access This article is distributed under the terms of the Creative Commons Attribution 4.0 International License (http://creativecommons.org/licenses/by/4.0/), which permits unrestricted use, distribution, and 
reproduction in any medium, provided you give appropriate credit to the original author(s) and the source, provide a link to the Creative Commons license, and indicate if changes were made.

\section{References}

1. Duyne, P.C. van, Harvey J., \& Gelemerova, L., (2016) 'The Monty Python Flying Circus of Money Laundering and the Question of Proportionality' Chapter 10 in 'Illegal Entrepreneurship, Organized Crime and Social Control: Essays in Honour of Professor Dick Hobbs' (ed) G. Antonopolous, Springer, Studies in Organized Crime 14.

2. Unger, B., \& Linde, D. (2013). 'Research handbook on money laundering' Edward Elgar publishing. Cheltenham: UK.

3. FATF (2009). AML/CFT Evaluations and Assessments: Handbook for Countries and Assessors, Paris: FATF, available at http://www.fatf- gafi.org/media/fatf/documents/reports/Handbook\%20for\%20assessors.pdf.

4. Ferwerda, J. (2009). The economics of crime and money laundering: Does anti- money laundering policy reduce crime? Review of Law and Economics, 5(2), 903-929.

5. Savona, E.U. Maggioni M. A and Vettori B. (eds) (2007), 'Cost benefit analysis of transparency requirements in the company/corporate field and banking sector relevant for the fight against money laundering and other financial crime', Brussels: European Commission.

6. Harvey, J. (2005). An evaluation of money laundering policies. The Journal of Money Laundering Control, 8(4), 339-345.

7. Arnone, M., \& Borlini, L. (2010). International anti-money laundering programs. Empirical assessment and issues in criminal regulation. Journal of Money Laundering Control, 13(3), 226-271.

8. Unger, B., Rawlings, G., Siegel, M., Ferwerda, J., de Kruijf, W., Busuioic, M., \& Wokke, K. (2006). The amounts and the effects of money laundering. In Report for the Ministry of Finance.

9. Ferwerda, J., Kattenberg, M., Chang, H., Unger, B., Groot, L., \& Bikker, J. (2013). Gravity models of trade-based money laundering. Applied Economics, 45(22), 3170-3182.

10. Reuter, P. (2013). Are the estimates of the volume of money laundering either feasible or useful? In B. Unger \& D. van der Linde (Eds.), Research handbook on money laundering. Edward Elgar: Cheltenham.

11. HM Treasury and Home Office (2017). National risk assessment of money laundering and terrorist financing, October.

12. Levi, M. (2003) Following the criminal and terrorist money trails. In van Duyne, P., von Lampe, K. and Newell, J. (eds) Criminal finances and Organising crime in Europe. Nijmegen, The Netherlands: Wolf Legal Publishers.

13. Ulph, J. (2010). Confiscation orders, human rights, as penal measures' Law. Quarterly Review, 126(Apr), 251-278.

14. King, Colin (2013). Follow the money trail: 'civil' forfeiture of 'criminal' assets in Ireland. In: van Duyne, Petrus C, Harvey, Jackie, Antonopoulos, Georgios A, von Lampe, Klaus, Maljević, Almir and Spencer, Jon (Eds.), Human dimensions in organised crime, money laundering, and corruption (pp. 265291). Nijmegen: Wolf Legal Publishers.

15. Duyne, P.C. Van, Zanger, W. de and Kristen, F.H.G. (2014). Greedy of crime-money. The reality and ethics of asset recovery. In P.C. van Duyne, J.H. Harvey, G.A Antonopoulos, K von Lampe, A Maljevic and A Markovska, Corruption, greed and crime money. Sleaze and shady economy in Europe and beyond. Wolf Legal Publishers.

16. Rui, J. P. (2011). The civil asset forfeiture approach to organised crime - Exploring the possibilities for an EU model 'The European Criminal Law Associations. Forum, 4, 153-161.

17. Agency, S. O. C. ((SOCA), (2009)). Annual Report, 2008/9. May: COI on behalf of the Home Office.

18. Harvey, J. L., \& F, S. (2009). Crime-money, reputation and reporting. Crime Law and Social Change, $52(1), 57-72$.

19. Duyne van, P. C. (2013). Crime, money and financial conduct. In Chapter 19 in E. Unger and D.van der Linde (eds: Research handbook on money laundering. Cheltenham. Edward Elgar.

20. Bosworth-Davies, R. (2007). Money laundering-chapter five: The implications of global money laundering laws. Journal of Money Laundering Control, 10(2), 189-208.

21. Duyne, P.C. Van, Soudijn, M. and Kint, T. (2009) 'Bricks don't talk. Searching for crime money in real estate'. In: P.C. Van Duyne, S. Donati, J. Harvey, A. Maljevic and K. von Lampe (eds.), Crime, money and criminal mobility in Europe. Nijmegen, Wolf Legal Publishers.

22. Levi, M. (2015). Money for crime and money from crime: Financing crime and laundering crime proceeds. Eur J Crim Policy Res, 21, 275-297.

23. Levi, M., \& Reuter, P. (2006). Money Laundering. Crime and Justice, 34(1), 289-375. 
24. Duyne, P. C., Groenhuijsen, M. S., \& Schudelaro, A. A. P. (2005). Balancing financial threats and legal interests in money-laundering policy. Crime, Law and Social Change, 43(2-3), 117-147.

25. Masciandaro, D. (1998). Money laundering regulation: The micro economics. Journal of Money Laundering Control, 2(1), 49-58.

26. Simpson, S. (2000). Of crime and criminality: The use of theory in everyday life. Thousand Oaks: Pine Forge Press.

27. Kaufman, B. (1998). Emotional arousal as a source of bounded rationality. Journal of Economic Behavior and Organization, 38, 135-144.

28. Cornish, D., \& Clarke, R. (1987). Understanding crime displacement: An application of rational choice theory. Criminology, 25(4), 933-947.

29. Clarke, R. V., \& Cornish, D. B. (1985). Modelling Offenders' Decisions: A Framework for Research and Policy. In M. Tonry \& M. Morris (Eds.), Crime and Justice: An Annual Review of Research (Vol. 6). Chicago: University of Chicago Press.

30. Clarke, R. V. (1995). In M. Tonry \& D. Farrington (Eds.), 'Situational crime prevention' in Building a Safer Society: Strategic Approaches to Crime Prevention. Chicago: The University of Chicago Press.

31. Cornish, D. B. (1993) 'Theories of Action in Criminology: Learning Theory and Rational Choice Approaches'. In R. V. Clarke and M Felson (eds) "Routine Activity and rational Choice". Advances in Criminological Theory. Vol 5. New Brunswick: Transaction Press.

32. Pogarsky, G., Roche, S. P., \& Pickett, J. T. (2017). Heuristics and biases, rational choice, and sanction perceptions. Criminology, 55, 85-111.

33. Collins, M. and Loughran, T. (2017) Rational Choice Theory, Heuristics and Biases, Chapter 2 pp in The Oxford Handbook of Offender Decision Making edited by Bernasco, W., Elffers, H., and van Gelder J., Oxford University Press.

34. Blickman, T. (2009). Countering illicit and unregulated money flows: Money laundering, tax evasion and financial regulation. TNI Briefing Series: Crime and Globalisation Debate Papers.

35. Simon, H. (1972) 'Theories of bounded rationality' chapter 8, pp. 161-176 in McGuire C and Radner R (Eds) Decision and Organization, North Holland Publishing Co.

36. Gnutzmann, H., McCarthy, K. J., \& Unger, B. (2010). Dancing with the devil: Country size and the incentive to tolerate money laundering. International Review of Law and Economics, 30, 244-252.

37. Argentiero, A., \& Busato, M. B. F. (2008). Money laundering in a two-sector model: Using theory for measurement. European Journal of Law and Economics, 26, 341-359.

38. Clarke, R. V. (1983) 'Situational crime prevention: Its theoretical basis and practical scope' In M. Tonry and M. Morris, (eds) Crime and Justice: An Annual Review of Research, Vol 4. Chicago Press.

39. Hornsby, R., \& Hobbs, D. (2007). A zone of ambiguity: The political economy of cigarette bootlegging. British Journal of Criminology., 47(4), 551-571.

40. Harvey J and Hornsby R (2016) The Criminal Entrepreneur: a case study of an organised criminal family in van Duyne, PC, Scheinost, M, Antonopoulos, G, Harvey, J and von Lampe K (eds.) Narratives on organised crime in Europe: criminals, corrupters and policy Wolf Legal Publishers, Nijmegen.

41. Croall, H. (1989). Who is the white-collar criminal. British Journal of Criminology, 29(2), 157-174.

42. Levi, M. (1987). Regulating fraud: White-collar crime and the criminal process. London: Tavistock.

43. Fleming, M. H. (2005). UK law enforcement agency. Use and Management of Suspicious Activity Reports': Towards Determining the Value of the Regime. London: JDI/Home Office.

44. Masciandaro, D. (2004). Money laundering: The economics of regulation. European Journal of Law and Economics., 7, 225-240.

45. Naylor, R. T. (1999). Washout: A critique of follow-the-money methods in crime control policy' Crime Law and. Social Change, 32, 1-57.

46. Levi, M. Osofsky, L. (1995) 'Investigating, Seizing and Confiscating the Proceeds of Crime' Police Prevention Group. Crime Detection and Prevention Series: Paper 61. London: Home Office Police Department.

47. Fried, D. J. (1988). Rationalizing Criminal Forfeiture. '. Journal of Criminal Law and Criminology, $79(2), 328-436$.

48. Levi, Michael \& Duyne, P. (2007). Drugs and Money: Managing the Drug Trade and Crime-Money in Europe. Organizational Crime. London: Routledge.

49. Duyne, P.C. van and Soudijn, M.R.J. (2010), Crime-money in the financial system: What we fear and what we know. In: M. Herzog-Evans (ed.), Transnational criminology manual, Volume 2, Nijmegen, Wolf Legal Publishers.

50. Fagan, J. (1994), 'Do criminal sanctions deter drug crimes?' in Mackenzie and Uchida (eds.), Drugs and Crime.

51. Gold, M. and Levi, M. (1994) Money Laundering in the UK: An Appraisal of Suspicious-Based Reporting: London: The Police Foundation/University of Wales. 
52. Adler, P. (1993). Wheeling and dealing (2nd ed.). New York: Columbia U.P.

53. Shover, N., \& Honaker, D. (1992). The socially bounded decision making of persistent property offenders. The Howard Journal of Criminal Justice, 31, 276-293.

54. Maguire, M. (1982). Burglary in a dwelling. Aldershot: Gower.

55. Levi, M. (1981). The phantom capitalists: The organisation and control of long-firm fraud. London: Heinemann.

56. Cuellar, M. F. (2003). The tenuous relationship between the fight against money laundering and the disruption of criminal finance. Journal of Criminal Law and Criminology. Vol. 93. Issue 2. Article, 1, 311-466.

57. Duyne, van, P.C. (2003) 'Money laundering policy. Fears and facts'. In: P.C. van Duyne, K. Von Lampe and J.L. Newell (eds.), Criminal finances and organising crime in Europe. Nijmegen, Wolf Legal Publishers.

58. Harvey, J. (2014). Asset recovery substantive or symbolic. In C. King \& C. Walker (Eds.), Dirty assets: Emerging issues in the regulation of criminal and terrorist assets. Farnam: Ashgate Publishing.

59. Duyne, P. C. (2009). Van and Vander Beken, T. (2008), 'the incantations of the EU organised crime policy making' Crime Law. Social Change, 51, 261-281.

60. Levi, M. (2002). 'Money laundering and its regulation' Annals of the American Academy of Political and Social Science. July, 582, 181-194.

61. Sproat, P. A. (2011). The serious and organised crime agency and the National Crime Squad: A comparison of their output from open source materials. Policing and Society, 21(3), 343-351.

62. Verhage, A. (2009). Compliance and AML in Belgium: A booming sector with growing pains. Journal of Money Laundering Control, 12(2), 113-133.

63. Duyne, P. C. Van (2006) "Money laundering and Predicate Crime in Serbia 2000-2005". Organisation for Security and Cooperation in Europe. Report available at: http://polis.osce.org/library/f/2641/378 /OSCE-SRB-RPT-2641-EN- Report\%20on\%20Money\%20Laundering\%20and\%20Predicate\%20 Crime\%20in\%20Serbia\%202000-2005.pdf.

64. Masciandaro, D., \& Filotto, U. (2001). Money laundering regulations and black compliance costs. What do your customers know? Economics and the Italian experience. Journal of Money Laundering Control., $5(2), 133-145$.

65. Verhage, A. (2011). 'The anti-money laundering complex and the compliance industry'. Routledge studies in crime and economics. UK: Oxon.

66. Harvey, J. (2008). Just how effective is money laundering legislation'? The. Security Journal, 21, 189-211.

67. Duyne, P.C. Van (2006). 'Witwasonderzoc, Luchtspiegelingen en de menselijkemaat', Justitiele verkenningen.32 (2) "Quoted in Unger "Scale and Impact of Money Laundering" (2007). Edward Elgar Publishing Ltd.

68. Llamputtong, P. (2011). 'Focus group methodology' principles and practice. London: Sage Publications.

69. Krueger, R. A., \& Casey, M. A. (2000). Focus groups: A practical guide for applied research. Thousand Oaks: Sage.

70. Pole, C. and Lampard, R. (2002) Practical social investigation 3rd edition. London: Prentice Hall.

71. Fowler, J. F. (2009) Survey Research Methods 4th edition. Thousand Oaks: Sage Publications Limited.

72. Morgan, D. L. (1988). 'Focus groups as qualitative research' qualitative research methods series 16. A Sage University Paper.

73. Braun, V., \& Clarke, V. (2006). Using thematic analysis in psychology. Qualitative Research in Psychology, 3(2), 77-101.

74. Bernard, H. R. (2000). Social research methods: Qualitative and quantitative approaches (4th ed.). Thousand Oaks: Sage Publications Inc..

75. Onwuegbuzie, A. J., \& Leech, N. L. (2007). A call for qualitative power analyses. Quality and Quantity: International Journal of Methodology, 41, 105-121.

76. Wilkinson, S. (2004). Focus group research. In D. Silverman (ed.), qualitative research: Theory, method, and Practice (pp. 177-199). Thousand Oaks: Sage.

77. Sim, J. (1998). Collecting and analyzing qualitative data: Issues raised by the focus group. Journal of Advanced Nursing, 28, 345-352.

78. Krueger, R. A. (1994). Focus groups: A practical guide for applied research', (2 ${ }^{\text {nd }}$ Edition). London: Sage.

79. Kitzinger, J. (1994). The methodology of focus groups: The importance of interaction between research participants. Sociology of Health and Illness, 18, 103-121.

80. Unger, B. (2007). 'The scale and impact of money laundering' contribution from Elena Madalina Busuioc. UK: Edward Elgar Publishing. 